\title{
Newton for ladies: gentility, gender and radical culture
}

\author{
MASSIMO MAZZOTTI*
}

\begin{abstract}
Francesco Algarotti's Newtonianism for Ladies (1737), a series of lively dialogues on optics, was a landmark in the popularization of Newtonian philosophy. In this essay I shall explore Algarotti's sociocultural world, his aims and ambitions, and the meaning he attached to his own work. In particular I shall focus on Algarotti's self-promotional strategies, his deployment of gendered images and his use of popular philosophy within the broader cultural and experimental campaign for the success of Newtonianism. Finally, I shall suggest a radical reading of the dialogues, reconstructing the process that brought them to their religious condemnation. What did Newtonianism mean to Algarotti ? In opposition to mainstream apologetic interpretations, he seems to have framed the new experimental methodology in a sensationalistic epistemology derived mainly from Locke, pointing at a series of subversive religious and political implications. Due to the intervention of religious authorities Algarotti's radical Newtonianism became gradually less visible in subsequent editions and translations. It is only through the study of the first - clandestine - edition of the dialogues that one can begin reconstructing the meaning of Algarotti's experiments (real and fictional) and his cultural battle for a regenerated Europe.
\end{abstract}

Francesco Algarotti's Newtonianism for Ladies, or Dialogues on Light and Colours (1737) was an eighteenth-century best-seller. It was also one of the main channels through which Newtonian ideas reached the general public in continental Europe. The book offered a description of some of Newton's experiments on the nature of light and colours in the form of a genteel dialogue between a chevalier (cavaliere) and a marchioness (la marchesa di $\left.E^{* * *}\right)$. Through an enjoyable, mundane and apparently lighthearted conversation, past doctrines about the nature of matter and light were sketched, considered and proved mistaken. Along the way, Algarotti gracefully disposed of contemporary anti-Newtonian philosophers as well. At the end of her initiation into the true philosophy the marchioness could not but agree that Newton's theory of light, and indeed his entire philosophical system, provided a veritable description of the functioning of the machine of the world. ${ }^{1}$

* Department of Sociology, University of Exeter, Amory Building, Exeter, EX4 4RJ.

I would like to thank for their support Giuliano Pancaldi, director of the International Centre for the History of Universities and Science at the University of Bologna, and the Italian Ministry for Universities and Research. I am also grateful to Mario Biagioli, Marta Cavazza, Moti Feingold, John Henry and Sven Widmalm for their comments on earlier versions of this paper, and to personnel at the Dibner Institute for the History of Science and Technology and the Burndy Library who, as usual, have provided me with the most efficient assistance. All translations from Italian sources are my own, unless otherwise stated.

1 F. Algarotti, Il newtonianesimo per le dame ovvero dialoghi sopra la luce e i colori, Naples [i.e. Milan], 1737. No publisher's name is given, and the usual approval of religious and political authorities is missing. Algarotti's explicit model was Fontenelle, Entretiens sur la pluralité des mondes (1686). Newtonianism for 
The book is divided into six dialogues taking place on five consecutive days. The dialogues are staged in a villa near Lake Garda, in the mainland part of the Venetian Republic. The country villa was a typical site of leisure, where the Venetian upper classes would spend the hot summer days gambling, reading poetry and enjoying conversation. Algarotti skilfully used the possibilities offered by the various spaces of the villa (dining room, gallery of paintings, garden and fountains) to stage the spectacle of Newtonian experimental philosophy. In the first dialogue the chevalier is reading aloud a poem celebrating the Bolognese Professor Laura Bassi as a Newtonian philosopher. This canzone had been published by Algarotti himself in 1732 to celebrate Bassi's graduation from the University of Bologna. A reference to the complex nature of light stimulates the curiosity of the marchioness, who asks for the reading to be suspended; she wants to know more about the new philosophy of light. Reluctantly, the chevalier agrees to sketch a 'Newtonian painting' for her; that is, to introduce her into the exciting world of Newtonian philosophy. ${ }^{2}$

The marchioness goes through a process of initiation, a 'noviciate', which begins with a historical overview of various systems of the universe and their respective doctrines on the nature of matter and light. The conversation touches upon Lucretius, Dante and medieval scholastic philosophy up to the moderns, primarily Descartes and Malebranche. The marchioness enjoys this agile and witty promenade through the history of philosophy as if she were at the opera, philosophers and system-makers being the hidden machinists who set up marvellous spectacles for the pleasure of her imagination. It takes the first three dialogues for the marchioness to travel through the imaginary realms of past philosophy. She becomes, at first, a fervent Cartesian. Then, made aware of the difficulties raised by the Cartesian theory of light, she decides to defend a more cautious Malebranchian position. By the end of the third dialogue, though, it is clear that this position must also be abandoned. Like any other imaginary system, the Malebranchian fails the test of empirical evidence. Rival theories are tested through simple, enjoyable, home-made experiences, like looking at the colours produced by the sparkle of a decorative fountain. Alternatively, the chevalier provides careful descriptions of professionally conducted experiments, usually those he has replicated himself or, at least, those of which he has witnessed the replication. The chevalier would ask the marchioness to imagine a certain state of affairs and follow step by step the imaginary replication of the experiment up to its final 'demonstration'. ${ }^{3}$

The fourth dialogue opens with a long 'eulogy of experimental philosophy', the 'industrious' matter-of-fact British tradition that culminated in Newton's work. His Opticks is presented here as the unsurpassed methodological model for experimental philosophy. It is at this point, in the middle of the book, that Algarotti begins describing

Ladies opened with a letter to Fontenelle, 'the most genteel philosopher of France', to whom the book is dedicated (pp. iii-xi).

2 Algarotti, op. cit. (1), 6-10. F. Algarotti, 'Non la Lesboa', in Rime per la famosa laureazione ed acclamatissima aggregazione al Collegio filosofico della ill.ma ed ecc.ma sig.ra Laura Maria Catterina Bassi, Bologna, 1732, 23-4. On the relations between Bassi and Algarotti see M. Cavazza, 'L'aurata luce settemplice. Algarotti, Laura Bassi e Newton', in M. Cavazza, Settecento inquieto. Alle origini dell'Istituto delle Scienze di Bologna, Bologna, 1990, 237-56.

3 Algarotti, op. cit. (1), 31, 47 and following. The opera metaphor is derived from Fontenelle, op. cit. (1). 
the optical experiments that have demonstrated the immutability and different refrangibility of colours. As the conversation moves towards the phenomenon of diffraction, it becomes clear that other mysteries have to be revealed to the marchioness in order to complete her philosophical initiation. In the sixth and final dialogue the chevalier hints at the connection between the optical laws and the universal law that rules the behaviour of material bodies, revealing the truly universal scope of the Newtonian system. The marchioness is, at that point, 'a true Newtonian'.

Although famous in the mid-eighteenth century, Newtonianism for Ladies has since then enjoyed little fortune. Historians of literature have generally disliked its rococo setting, its frivolous tone and its polluted, Frenchified language. Similarly, historians of science and culture have paid little attention to this book, considering it superficially anglophile and merely devoted to the popularization of natural philosophy. Overall, only a few scholars seem to have actually gone through its pages, and even less through those of its semi-clandestine first edition. The assumption that the production of scientific knowledge and its popularization should be studied and understood as two distinct spheres of action has certainly contributed to obscuring the historical and cultural significance of the book. ${ }^{5}$ Instead, in the present essay it will be suggested that for Algarotti to create a lay public for Newtonian experimental philosophy was an essential part of his overall pro-Newtonian campaign. In acting as an academic experimenter or as a popular writer Algarotti was following one and the same strategy: building alliances that would isolate his opponents while strengthening the position of Newtonianism on the continent. Genteel conversation and light-hearted literature could succeed where scientific instruments, and prisms in particular, had so far failed. ${ }^{6}$

Newtonianism for Ladies can indeed be studied as a complex literary mechanism designed to support various strategies. For one thing, it promoted the popularization of natural philosophy as an uplifting and pleasurable literary genre, thus being functional to Algarotti's self-fashioning as an independent cosmopolitan author. Behind the transparent mask of the chevalier, Algarotti emerged from the dialogues as a skilled experimenter and one of the champions of Newtonianism on the continent. More importantly, he presented himself as the only one able to popularize modern natural philosophy in the spirit of Fontenelle, making it the topic of pleasurable reading and conversation. The text, and particularly the presentation of the optical experiments on light and colours, should also convince readers of Newton's definitive victory over Platonic, Cartesian and Leibnizian doctrines. A few lay spectators, mostly from the Bolognese and Venetian aristocracy, had witnessed Algarotti's experiments in 1728 and 1729. But a much greater audience could be reached with their literary display.

4 Algarotti, op. cit. (1), 154.

5 On early remarks on Algarotti's superficiality see F. Algarotti, Opere, 17 vols., Venice, 1791-4, i, p. xiv. On early criticism of Algarotti's style and language see letter of Eustachio Manfredi to Algarotti (1738), in Algarotti, Opere, xii, 323-4. Most remarkable is the absence of any reference to Algarotti's book in H. Guerlac, Newton on the Continent, Ithaca, 1981.

6 On the integration of material, literary and scientific technologies in order to establish matters of fact see S. Shapin, 'Pump and circumstance: Robert Boyle's literary technology', Social Studies of Science (1984), 14, 481-520; and S. Shapin and S. Schaffer, Leviathan and the Air-Pump: Hobbes, Boyle and the Experimental Life, Princeton, 1985. 


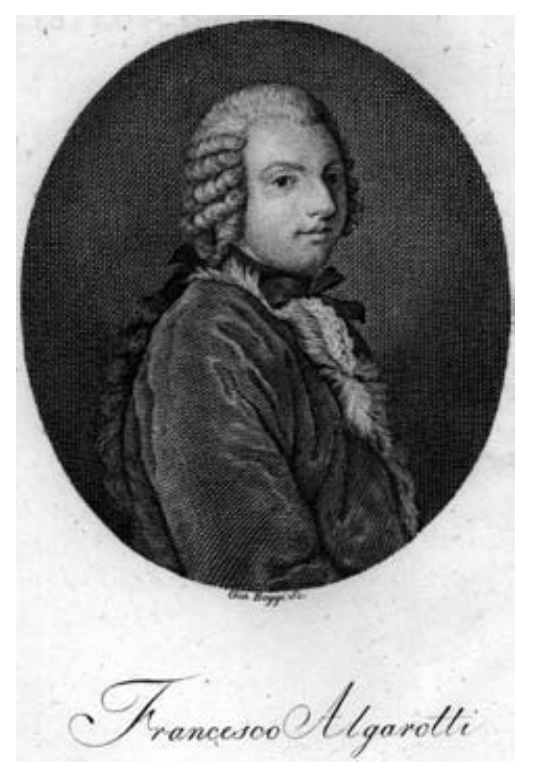

Figure 1. Francesco Algarotti. From F. Algarotti, Opere, 1823.

Algarotti represented experiments concretely, thus engendering in the reader the impression that, like the marchioness, they needed no further information in order to give their assent to Newton's final victory. Through the enrolment of non-academic supporters as virtual witnesses Algarotti aimed to secure the cultural and social isolation of those individuals and institutions that resisted Newtonianism. For all its apparent light-heartedness, his dialogues were indeed challenging the hegemony of rationalist and transcendentalist philosophies on the continent.

Algarotti's philosophical critique offered itself to a radical reading. The subversive dimension of his discourse emerged in minor remarks and divagations in which he deployed libertine and materialist motifs. In the background was his suggestion to embrace a sensationalist epistemology and to introduce the methodology of experimental philosophy into the realms of metaphysics, morals and politics. While the dangerous nature of Algarotti's presentation of Newtonianism has escaped many recent commentators, it did not escape the Holy Office in Rome. This was indeed the only popularization of Newtonian philosophy to end up on the Index of Prohibited Books (1739). Politics and subversion, then, but always in the mode of the most genteel and rococo levity, between a charming smile of the marchioness and a self-deprecating joke of the chevalier.

\section{The making of a cosmopolitan author}

The book opens in a rather unusual way, with Algarotti proudly recalling the way in which he turned himself into an 'author', someone whose natural desire is to be published and to be successful. Algarotti had a truly entrepreneurial attitude in the design, 
production and promotion of his Newtonianism for Ladies. He began tinkering with the dialogues in the late 1720s while studying in Bologna, and continued working on them for more than twenty years, the definitive edition appearing in 1752. Along the way the book changed both title and contents, going through numerous Italian editions and translations into French, English, German and Dutch. This long-lasting and troubled editorial project maps well onto Algarotti's restless life of those years, his ambitions and career-building moves. Algarotti conceived his book as a means to gain both economic independence and cultural legitimization; that is, the citizenship of the Republic of Letters. He put a great deal of energy into editorial matters, and was quite displeased with the quality of most of the translations. He judged that they had missed many of the original subtleties, thus compromising his success abroad. He was particularly concerned with the French translation by Louis-Adrien Du Perron de Castera, which circulated widely in Europe. Not only had Castera introduced a number of embarrassing scientific errors; he had also tried, through his comments, to rescue Cartesian doctrines from Algarotti's criticism. Algarotti's remarks were such that Castera had to respond by challenging him to a duel. ${ }^{7}$

The overall outcome of this publishing enterprise was quite disappointing. The book was certainly in demand, two hundred copies being pre-booked in the city of Venice alone, but the publishing system and the institution of authorship could not guarantee the kind of monetary return that Algarotti was expecting. With his attempt at making a living out of the popularization of natural philosophy falling short of expectations, around the year 1740 Algarotti began to rely on the patronage of enlightened rulers to support his literary career, most notably Fredrick II, King of Prussia and Augustus III, King of Poland and Elector of Saxony. However, thanks to the success of his book Algarotti had entered the Republic of Letters and established himself as a cosmopolitan author. ${ }^{8}$

Algarotti's enthusiastic cosmopolitanism was shaped by the cultural and political crisis of the Republic of Venice, his career following a pattern common to other eighteenth-century Venetian literati, artists and adventurers. The second-born male son of a

7 On Algarotti complaining about translations see his letter to Count Mazzuchelli (1751) in Algarotti, op. cit. (5), ix, 180-4. The first French edition was Le Newtonianisme pour le dames, ou entretien sur la lumiere, sur les couleurs, et sur l'attraction, Paris, 1738. See also [Algarotti], 'Lettre d'un Italien à un François au sujet des Entretiens sur le neutonianisme, traduits en françois par M. Du Perron de Castera', Observations sur les écrits modernes (1738), 15, 319-35; and Du Perron de Castera, Lettre à a M. le C.te de L*** pour répondre à celle d'un Italien, au sujet des Entretiens sur le newtonianisme, Paris, 1739. On some technical aspects of the French translation see C. Giovanardi, 'Note su Algarotti tradotto in francese', Nuovi Annali della Facoltà di Magistero dell'Università di Messina (1988), 6, 91-125. The first English translation was Sir Isaac Newton's Philosophy Explain'd for the Use of the Ladies. In Six Dialogues on Light and Colours, London 1739, translated by Elizabeth Carter (1717-1806) and published by Edward Cave (1691-1754), who also founded and directed the Gentleman's Magazine. See Algarotti's remarks on this translation in the Avvertenza of the 1739 Italian edition of the Newtonianesimo. Other English and French editions followed, as well as various editions in German and Dutch. See the full list in F. Arato, Il secolo delle cose. Scienza e storia in Francesco Algarotti, Genoa, 1991, 136-55.

8 Other Venetian authors were experiencing similar problems, including the successful playwright Carlo Goldoni. See M. Infelise, L'editoria veneziana nel '700, Milan, 1989. For a Gramscian reading of Algarotti's condition at the court of Fredrick II see A. Lepre, 'Federico il Grande e l'Algarotti', Belfagor (1961), 16, 284-97. 
wealthy Venetian merchant, Francesco Algarotti (1712-64) spent little time in his native city. After one year at the Collegio Nazareno in Rome he moved to Bologna, where he studied under the supervision of eminent professors like the astronomer Eustachio Manfredi and the natural philosophers Francesco Maria Zanotti and Jacopo Beccari. He studied calculus, astronomy and experimental physics. In 1728 Algarotti was encouraged to conduct the replication of some of Newton's experiments on the refraction of light and the immutability of colours. This series of experiments, held in the rooms of the Institute of Sciences of Bologna, was the most scrupulous and carefully documented replication of Newton's optical experiments carried out on the continent to that date. To many scholars the outcome of these experiments proved once and for all the validity of the Newtonian system against the doubts being raised in some scientific circles. ${ }^{9}$

Algarotti soon decided to make his fortune abroad. The family trading business was already in the hands of his brother Bonomo, while the possibility of an ecclesiastic career had been discarded after the death of a third brother, which put at risk the integrity of the family patrimony. At that point it was decided that Francesco should pursue a lay career and marry into a good family. As for him, he had quite different plans altogether. Convinced that marriage would have been 'like death' for him, and hardly attracted by the intrigues of university life in Bologna, Algarotti aspired to some kind of literary or diplomatic career. He had little chance of achieving a prestigious position in Venice, not being a member of the restricted oligarchy that ran the republic. In fact, Algarotti was not even a nobleman, and the Most Serene Republic refused to charge him with any diplomatic duty while he was living abroad. After considering various possibilities, including a risky speculation in the West Indies, he decided to concentrate his efforts on the making of Newtonianism for Ladies. ${ }^{10}$

Algarotti had been experiencing salon life since his student years in Bologna. He had been a protégé of Marchioness Elisabetta Ratta, who took care of publishing his early poetry and to whom, as late as 1741, Algarotti would send his own translation of Petronius to be read in her conversazione. Algarotti was therefore well aware of specific social spaces and patterns of behaviour that could provide him with an alternative career. He soon decided that he would find his new homeland in that distinctively eighteenth-century world at the intersection of the Republic of Letters and European

9 In the following years Algarotti deepened his study of other aspects of Newton's work, as shown by his essay on Newtonian chronology. See F. Algarotti, Saggio sopra la durata de' regni de' re di Roma (1729), in Algarotti, op. cit. (5), iv, 127-70. For biographical information on Algarotti see G. M. Mazzuchelli, Gli scrittori d'Italia. Ciò notizie storiche e critiche intorno alle vite e agli scritti dei letterati italiani, 6 vols., Brescia, 1753-63, i, 479-86; D. Michelessi, 'Memorie intorno alla vita ed agli scritti del Conte Francesco Algarotti', in Algarotti, op. cit. (5), i, pp. i-cxxv; I. F. Yates, Un cosmopolite italien du XVIIIe siècle, Francesco Algarotti, Paris, 1913; E. Bonora, sub voce, Dizionario biografico degli italiani, Rome, 1960-, ii, 356-60 (henceforth $D B I$ ); and Arato, op. cit. (7). On Venetian society and culture see J. C. Davis, The Decline of the Venetian Nobility as a Ruling Class, Baltimore, 1962; G. Cozzi, 'Venezia, una repubblica di principi ?' Studi Veneziani (1986), 11, 139-58. See also F. Venturi, Settecento riformatore: da Muratori a Beccaria, Turin, 1969; and G. Arnaldi and M. Pastore Strocchi (ed.), Storia della cultura veneta. Vol. 5/I and II, Vicenza, 1985-6.

10 On marriage like death see Algarotti’s letter to Bonomo (1733), mss 1256 A, Biblioteca Comunale, Treviso (henceforth BCT). On the 'academic cabals' in Bologna see the letter of Algarotti to Zanotti (1732), in Algarotti, op. cit. (5), xii, 66. Algarotti received the title of count from Frederick II in 1740. 
high society. As a would-be independent author he would rely solely on his own literary reputation. Interestingly, in the years following the publication of Newtonianism for Ladies Algarotti would widen the range of his cultural products, devoting himself to the art trade and to the emerging profession of literary and art critic. In a period of crucial transition from il mondo to public opinion Algarotti was trying, with mixed fortunes, to cut his audience out of what he liked to define as 'the graceful people' (la leggiadra gente). ${ }^{11}$

Travelling was essential to the shaping of Algarotti's cosmopolitan career. He left Bologna in 1732, to refine his knowledge of Greek and Latin poetry. He visited Padua and the Veneto, then Florence and Rome. As emerges from his letters, frequenting conversazioni in these cities he came in touch with a colourful world of adventurers, gamblers and Jacobite exiles. In the spring of 1734 Algarotti decided to join Anders Celsius on his journey from Rome to Paris. Maupertuis and Clairaut welcomed him in their circle, while Italian diplomats guided him through the conventions of local high society. Algarotti worked his way quickly through Parisian salons, where his androgynous charm, brilliant conversation and apparently bottomless riches did not go unnoticed. His new acquaintances ignored the fact that he was constantly negotiating with his older brother in Venice in order to receive enough money to support his conspicuous Parisian lifestyle. Algarotti insisted this was only a temporary situation; he was confident he would soon make his own fortune. ${ }^{12}$

Algarotti's determination to complete his book quickly was such that he declined Maupertuis's invitation to join the 1735 scientific expedition to Lapland. At that time Algarotti was sojourning at the château of Cirey, the summer residence of Emilie du Châtelet. Here he could read his work to Châtelet and Voltaire, while preparing its publication in the best possible conditions. The secluded and pleasurably intellectual life at Cirey had a clear impact on the dialogues. Algarotti described it as 'a life spiced by the pleasures of the mind'. What could have been more appropriate for somebody who was trying to transfuse scientific matters into the moulds of 'the good manners of conversation'? The frontispiece of the first edition of Newtonianism for Ladies is

11 On Bolognese salon life see Michelessi, op. cit. (9), pp. cxxi-cxxii. On Petronius's translation see the letter of Eustachio Zanotti to Algarotti (1741), in Algarotti, op. cit. (5), xii, 366. On Algarotti willingly placing his fate in the hands of the public see his letter to Bonomo dated 4 December 1737, mss 1256 A (BCT). See Algarotti's letter (1763) to an anonymous recipient on the elusive audience, still in the making, he aimed to address, which he situated somewhere in between 'the learned' and 'the ignorant', in Algarotti, op. cit. (5), x, 173. See also D. Goodman, The Republic of Letters: A Cultural History of the French Enlightenment, Cornell, 1994, 236; and, for a European overview, J. Van Horn Melton, The Rise of the Public in Enlightenment Europe, Cambridge, 2001. On the commodification of culture products in the eighteenth century see also J. Habermas, The Structural Transformation of the Public Sphere: An Inquiry into the Category of Bourgeois Society, Boston, 1991, 25-6, 36-7.

12 Algarotti had been preceded by letters to Maupertuis and Jean-Jacques Dortus de Mairan. Letter of Manfredi to Algarotti (1734), in Algarotti, op. cit. (5), xi, 112. However, Manfredi insisted that he should rather get married and settle down in Venice, where he could 'carry on a most sweet and pleasant life'. Letter to Algarotti (1732), in Algarotti, op. cit. (5), xi, 74. On increasing his allowance see the letter of Algarotti to Bonomo, dated 17 April 1734, mss 1256 A (BCT); and the letters of Bonomo to his brother, mss 1256 B (BCT). See also Yates, op. cit. (9), 45-9. 


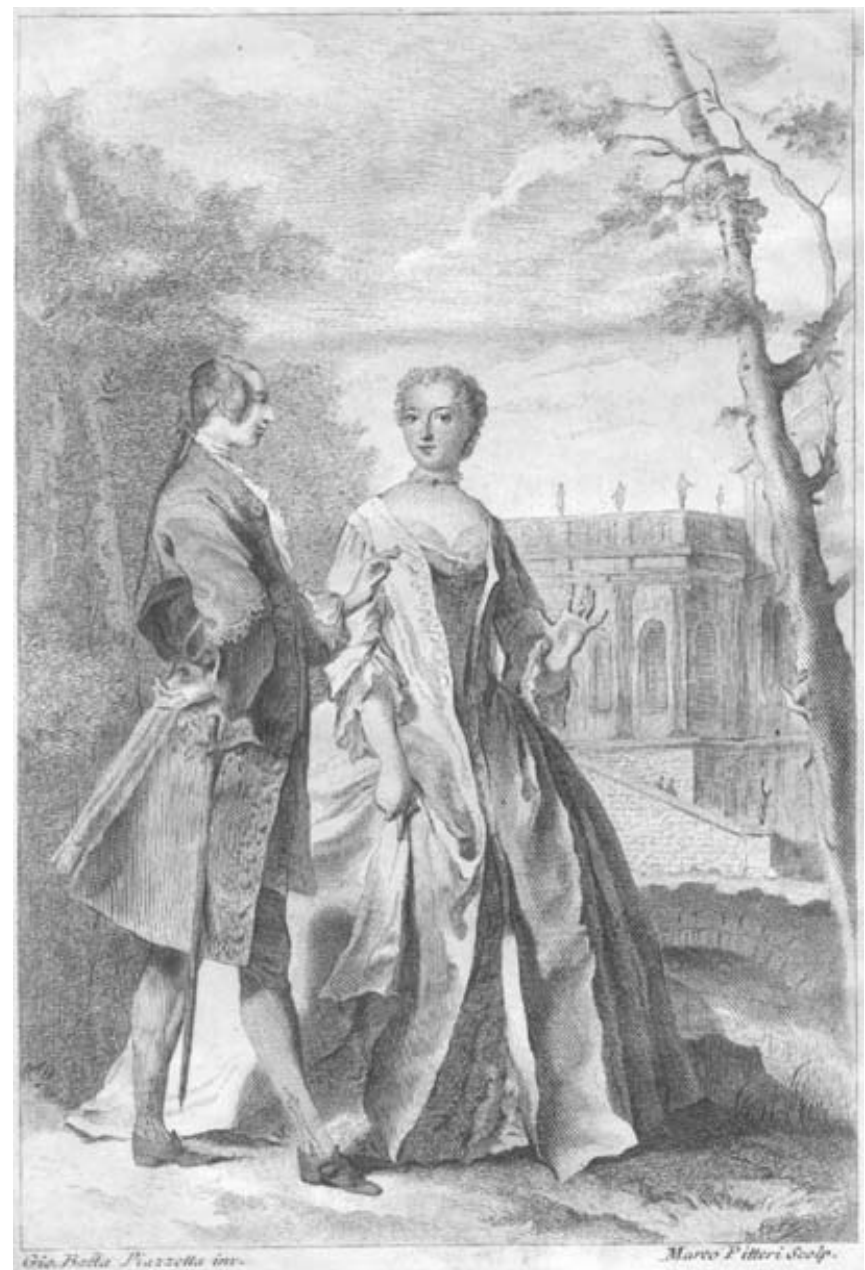

Figure 2. Frontispiece of the first edition of the Newtonianism for Ladies, 1737.

indeed a souvenir of Cirey, the chevalier and the marchioness being portrayed in the semblance of Algarotti and Châtelet. ${ }^{13}$

The dialogues were concluded in 1736 during Algarotti's first visit to Britain. On that occasion Algarotti joined the Royal Society of London and was introduced into London society by two new fervent admirers: John Hervey and Mary Wortley Montagu. By the autumn Algarotti was back in Venice, trying to have the book published. Venetian

13 On the manners of conversations see Algarotti's letter to Franchini (1735), in Algarotti, op. cit. (5), ix, 3-4. Voltaire remarked that Algarotti had managed to be amiable in his book as he was in his conversation, Michelessi, op. cit. (9), p. cxxii. The engraving on the frontispiece was by Marco Pitteri based on a drawing by Giambattista Piazzetta. Letter of Châtelet to Algarotti (n.d.), in Algarotti, op. cit. (5), xv, 12. Manfredi did not like the idea of portraying a 'well-known lady'. Letter of Manfredi to Algarotti (1738), in Algarotti, op. cit. (5), xi, 131. See also Arato, op. cit. (7), 138; and Michelessi, op. cit. (9), pp. xvi-xvii. 
publishers were not too keen on printing a book of that kind without imprimatur, and Algarotti opted for the Austrian-ruled city of Milan, where the cultural atmosphere proved to be more favourable to the enterprise. The first copies of Newtonianism for Ladies came off the press at the end of 1737 , without permission and with the forged imprint of Naples. ${ }^{14}$

\section{Gentility and gender}

In his dialogues Algarotti deployed a series of gendered images and associations that deserve particular attention. He began from the very title page, where he referred to his female audience not only with the indication 'for ladies' but also with the motto quae legat ipsa Lycoris ('Lycoris herself may read'), a malicious reference to a courtesan of ancient Rome. Gendering knowledge could be functional in reinforcing the authority of modern experimental philosophers while facilitating the construction of an audience for popular science. This gendered discourse and the choice of the topic of optics allowed Algarotti to celebrate the mathematical core of Newtonian philosophy while in fact removing it from the sight of the audience. ${ }^{15}$

At various points Algarotti suggested the association of abstract thinking and mathematical practice with masculinity, in opposition to a supposedly female inclination for feelings, imagination and social skills. In these passages Algarotti was endorsing and reinforcing a gendered view of the intellectual faculties that was to become a common feature of late Enlightenment culture. In this respect the character of the marchioness functioned as a rhetorical device to naturalize the representation of certain attitudes and inclinations as specifically feminine. It should be noted that these feminine attitudes, like being amathematical or overly imaginative, were precisely those used by Algarotti to explain the errors of ancient philosophers and of the contemporary foes of Newtonianism. Against this background of feminine deficiencies, the cognitive and moral virtues of the Newtonian philosopher became all the more apparent.

14 Algarotti was recommended to the Royal Society by Martin Folkes, Anders Celsius and Andrew Mitchell. He sat a session of the society on 1 April 1736 and was elected a member on 8 July. See Arato, op. cit. (7), 39. Hervey and Montagu were apparently bewitched by Algarotti's charm. Algarotti 'had powers of pleasing and used them' (L. Moore, Amphibious Thing: The Life of a Georgian Rake, London, 2000, 242). See R. Halsband, The Life of Lady Mary Wortley Montagu, Oxford, 1957; R. Halsband, Lord Hervey, Eighteenth Century Courtier, Oxford, 1973; and Lord Hervey's Memoirs (ed. R. Sedwick), London, 1848. On Algarotti's homosexual inclinations see also P. Toldo, 'L'Algarotti oltr'Alpe', Giornale storico della letteratura italiana (1918), 33, 25. Algarotti had planned to dedicate his book to the Emperor Charles VI but was dissuaded by his Bolognese friends. See letter of Zanotti to Algarotti (1737), in Algarotti, op. cit. (5), xii, 184-5; and letter of Manfredi to Algarotti (1737), in Algarotti, op. cit. (5), xi, 127. For further references on the then Milanese environment see Arato, op. cit. (7), 137-8.

15 Algarotti presented to his readers the experimental philosophy of Newton's Opticks as essentially related to Newton's work on calculus and to the mathematical natural philosophy of his Principia. On the popular influence of Newton's Opticks see M. H. Nicolson, Newton Demands the Muse: Newton's Opticks and the Eighteenth Century Poets, Princeton, NJ, 1946. The motto is taken from the opening lines of Virgil, Ecoglae, x: 'Extremum hunc, Arethusa, mibi concede laborem:/panca meo Gallo, sed quae legat ipsa Lycoris,/carmina sunt dicenda; neget quis carmina Gallo?' (This last labour, Arethusa, grant to me: verses must be sung for my Gallus, few, yet such as Lycoris herself may read: who would deny verses to Gallus?). Lycoris was the courtesan loved by the poet Gallus. 
Thus the marchioness tends to react to the teaching of her tutor as an emblematic representative of 'that sex that prefer to feel rather than to know'. Often the prey of uncontrolled passions, along the way to her philosophical initiation she is shaken by successive and opposite feelings towards the main systems of the world. Only thanks to the chevalier's dispassionate guidance can she finally glimpse the real functioning of the world as unveiled by Newton's philosophy. It is just a glimpse, though. By the end of the book the marchioness is well aware that she can go only so far in the long and impervious study of natural philosophy, given that she 'cannot enter the sanctuary of geometry'. The marchioness is not only weak in mathematics, she is also overly imaginative. Imagination is important for visualizing experiments, and hence consuming popularized natural philosophy, but when not kept properly under control it can become the worst enemy of correct reasoning. Imagination can easily 'infect' physics. Much of the chevalier's critique of Cartesianism was directed precisely at its excessive reliance upon the faculty of imagination. Too fervent an imagination causes people to deny matters of fact, an unhealthy inclination that philosophers like Descartes share with other deviant figures like 'silly women and enthusiasts'. By contrast, the Newtonian philosopher is nothing short of an 'ideal man', curious, active, dispassionate, circumspect and perfectly mannered. He certainly cannot be intimidated by the authority of past authors or seduced by his own imagination. ${ }^{\mathbf{1 6}}$

One could conclude that Algarotti was portraying mathematized natural philosophy as an exclusive male reserve, due to the natural intellectual inclinations of men and women. But was he? Not quite. Algarotti was certainly deploying gendered associations to fight the battle for Newtonianism. However, while mapping the moral and intellectual virtues of the Newtonian philosopher against the positive values of masculinity, Algarotti did not put forward a theory of the female mind. Nor was he defending a distinction between the male and female mind based on physical differences. Some passages seem rather to portray the gendering of faculties as the product of a historical process. Thus, at the end of their conversation, the chevalier invites the marchioness to be wise, and to dissimulate her knowledge of Newtonianism when she would be acting again in the public space of the salon. Doing otherwise, he whispers, would certainly harm the social life of a woman, even a sophisticated salonnière. Algarotti described his fictional marchioness as unusually ingenious and attentive for a woman; beautiful women, he remarked, tend indeed to abstain from the kind of attention that is a prerequisite of scientific education. Again the question was framed in historical and social terms rather than physical ones. At one point in the dialogue the chevalier even states that with the right kind of training the marchioness could became a mathematician herself (geometressa). One should not forget that Algarotti had studied in a world in which women could be perceived as legitimate natural philosophers and mathematicians. During the first half of the eighteenth century in Italy, and particularly in Bologna, a few learned women, most notably Laura Bassi and Maria Gaetana Agnesi, were acknowledged and rewarded by universities and academies. It was not by coincidence that the chevalier stimulated the marchioness's curiosity by reading a poem in

16 Quotes from Algarotti, op. cit. (1), p. v, 277, 255, 262, 179, 180-1. 
which Algarotti celebrated the graduation of his friend Laura Bassi, Newtonian philosopher and skilled experimenter. ${ }^{17}$

Algarotti was thus presenting an ideal role model to upper-class Italian women, a group of avid consumers of poetry and novels, which he aimed to enrol in his audience. What he offered them was not some sort of scientifically flavoured poetry but a sample of a new literary genre that could go alongside poetry as a source of enjoyable reading, genteel conversation and new patterns of behaviour. Contrasting his work with the pedantic verses of much contemporary poetry Algarotti gave to his female audience a new style and new subject matters, which would result in 'a new kind of pleasure'. In the dialogues the marchioness is offered a discursive reconstruction of Newtonian experiments; she is asked to imagine various states of affairs; she is asked to reason (fare riflessione) and to follow the chevalier in the regions of philosophical warfare. This turns out to be a particularly pleasurable experience. She forgets about poetry and, for a few days, she does not enjoy any pastime that the villa can offer apart from philosophical conversation. Indeed, she becomes so excited that she can hardly sleep at night. This was a promise Algarotti was making to his readers about the pleasurable rewards of the new genre: it would be nothing short of falling in love. Interestingly, certain radical philosophical doubts are described as sources of incomparable pleasure for those who contemplate them. It is a case of the question of whether we all perceive the objects around us in the same way. But even the simple act of looking into a mirror can become, for those aware of certain simple optical laws, a source of endless philosophical pleasure. Algarotti reinforced these arguments using, throughout the dialogues, the well-suited metaphor of a theatre spectacle. Optical experiments, the chevalier guarantees, can offer 'the most beautiful spectacle you can ever imagine'. Their mere literary representation, and the description of the various systems of the world, can be more magnificent and pleasurable than many of the scenes seen at the opera. Note that the intellectual journey of the marchioness and her gradual shift in opinions and feelings also follow clear theatrical patterns. ${ }^{18}$

17 On the need for the marchioness to dissimulate her knowledge see Algarotti, op. cit. (1), 300; on the lack of attention see Algarotti, op. cit. (1), 5; on becoming a mathematician see Algarotti, op. cit. (1), 79. On Bassi see Algarotti, op. cit. (1), 6. Paula Findlen has identified two kinds of women natural philosophers portrayed in Newtonianism for Ladies; see P. Findlen, 'Becoming a scientist: gender and knowledge in eighteenthcentury Italy', Science in Context (2003), 16, 59-88. On the presence of women at the University of Bologna see M. Cavazza, 'Dottrici e lettrici dell'Università di Bologna nel Settecento', Annali di storia delle università italiane (1997), 1, 109-26. On Bassi see P. Findlen, 'Science as a career in Enlightenment Italy: the strategies of Laura Bassi (1711-1778)', Isis (1993), 84, 441-69; G. Berti Logan, 'The desire to contribute: an eighteenthcentury Italian woman of science', American Historical Review (1994), 99, 785-812; M. Cavazza, 'Laura Bassi e il suo gabinetto di fisica sperimentale: realtà e mito', Nuncius (1995), 10, 715-53; and B. Ceranski, Und sie fürchtet sich vor niemandem: Die Physikerin Laura Bassi (1711-1778), Frankfurt, 1996. On Agnesi see M. Mazzotti, 'Maria Gaetana Agnesi: mathematics and the making of Catholic Enlightenment', Isis (2001), 92, 657-83.

18 According to Michelessi, Algarotti aimed to take 'worthless novels' off the hands of women (Michelessi, op. cit. (9), p. xv). See also C. Lougee, Le Paradis des Femmes: Women, Salons, and Social Stratification in Seventeenth-Century France, Princeton, 1976; and Findlen, 'Becoming a scientist', op. cit. (17). On the 'new kind of pleasure' see Algarotti, op. cit. (1), p. x. That popular science could be the source of a new form of pleasure was a motif derived from Fontenelle. See also E. Harth, Cartesian Women: Versions and Subversions 
Staging optical experiences in the gallery of the villa or amidst the sprinkling of its fountains further suggested that philosophical matters could make a good topic not just for enjoyable prose but also for lively genteel conversation. Granted, for a genteel philosophical conversation to succeed the participants had to respect certain basic rules. Conversation, for instance, should never lose its distinctive levity. This did not mean watering down demonstrations or weakening philosophical reasoning, as when one uses metaphors that distract from the subject proper. Levity had more to do with domesticating apparently unsociable topics such as mathematical and mechanical sciences. Note how, in the dialogues of Newtonianism for Ladies, opinions, descriptions of scientific instruments, objections and colourful episodes follow one another providing the dialogues with a varied, entertaining structure. Boredom was indeed the great enemy of philosophical conversation. Algarotti's language, informed by conversational modes and rich in witty punch-lines, was well suited to his entertaining style. The language spoken by the two protagonists has indeed more to do with Baldassare Castiglione and Galileo Galilei than with Dante and Petrarch. ${ }^{19}$

By contrast dusty philosophers and obscure mathematicians were enemies of genteel philosophical conversation, as indeed were obnoxious Arcadian poets. It was not just a matter of topics but rather of style, language and savoir-faire; a matter of genteelness and taste (gusto). Taste was, according to Algarotti, an acquired faculty. It was the element that truly distinguished the graceful people, the bel mondo, from the rest. Taste was a product of the refinement of the spirit, which could be achieved through art, literature and natural philosophy. Algarotti often used the terms spirito and gusto to indicate the distinguishing traits of the new enlightened elite he aimed to represent and address. The marchioness's new pleasures derived precisely from her acquiring the art of cultivating her own spirit. And Algarotti liked to think of himself as one of the great 'traffickers of spirit' of his age. Cultivating one's own spirit through popular versions of Newtonian philosophy was an activity at once pleasurable and distinctive, quite like drinking tea, wearing English hats and studying the English language. Such activities became popular among Milanese ladies in the years following the appearance of Algarotti's Newtonianism for Ladies. ${ }^{20}$

of Rational Discourse in the Old Regime, Ithaca, 1992. On the pleasurable doubts about perception see Algarotti, op. cit. (1), 64; on opera: 31, 112; quotes: 77, 80.

19 On genteel philosophical conversation see Algarotti, op. cit. (1), 33, 218. The marchioness was indeed offended when the chevalier compared the Sun to one of her amber pastilles as they both emit particles (21-2). On Algarotti's ways of engaging the reader see also his own remarks in the opening letter to Fontenelle (pp. v-ix).

20 On the obscure language of Arcadian poets and bad philosophers see Michelessi, op. cit. (9), p. xxxii. See also Algarotti's satire against the baroque language of university philosophy: Sinopsi di una introduzione alla Nereidologia. Trattato filosofico, erudito e critico (MSS dated 1757), in Algarotti, op. cit. (5), vi, 332-85; and the letter of Algarotti to Madame du Boccage (1759), in Algarotti, op. cit. (5), xvii, 7. On the ways in which one can refine one's own gusto see Michelessi, op. cit. (9), pp. lv-lvi (among Algarotti's sources on taste are David Hume and John Addison). On Algarotti trafficker of spirit see Algarotti, op. cit. (1), p. xi. On English-mania in Milan see A. Graf, L'anglomania e l'influsso inglese in Italia nel secolo XVIII, Turin, 1911, particularly $225-6$ and $408-11$. On the relation between consumerism and the popularization of natural philosophy see also R. Porter, S. Schaffer, J. Bennett and O. Brown, Science and Profit in 18th-Century London, Cambridge, 1985. 
To be sure, Algarotti's expectations went well beyond the fancy hats of Milanese ladies. He hoped that the modern, cosmopolitan spirit he was promoting could transform the cultural and social life of the Italian upper classes. In this respect the character of the marchioness functioned as the emblem of a general, although clearly feminized, audience for the popularization of philosophy. This kind of audience was made up of graceful people who, like the marchioness, would not have been trained in 'modern geometry' (that is, the new science of calculus) because they did not have the time or inclination, or because it would have been socially counterproductive. The relationship between the marchioness and the chevalier pointed therefore also at the widening gap between a restricted expert elite, which might include a few exceptional women, and the general public. The specification 'for the ladies', not uncommon in those years, played on this duplicity and could be read as referring both to a female audience and to a general audience. In this sense, 'for the ladies' functioned similarly to James Ferguson's 'made easy to those who have not studied mathematics'. ${ }^{21}$

The popularization of Newtonianism in Britain, and particularly the best-selling books of the 1750s and 1760s, indeed followed similar patterns. Even here the commercialization of leisure was intertwined with processes of social emulation, the emphasis going to the possibility of acquiring taste, genteelness and refinement through the 'cultivation' of philosophy and the possession of scientific instruments. Style and form were also similar, being derived from the most popular literary models of the period: the dialogue and the epistolary novel. Feminine characters were pre-eminent, and figured invariably as bearers of politeness and gentility to otherwise arid philosophical matters. ${ }^{22}$

In Algarotti the connection between popularization and feminization emerged most clearly in the recurring metaphor of the 'domestication of philosophy'. This expression, already used by Fontenelle, referred to the transfer of knowledge from the secluded

21 Instead, Voltaire found the label 'for the ladies' somehow diminishing and titled his own popularization of Newton's philosophy Elémens de la philosophie de Neuton, mis à la portee de tout le monde, Amsterdam, 1738. Algarotti showed 'how every reasonable mind capable of average attention but lacking deep mathematical knowledge can nonetheless be filled with philosophical ideas', Michelessi, op. cit. (9), p. xv. See also Algarotti's letter to Marcantonio Caldani in Algarotti, op. cit. (5), ix, 355. The last quote is from J. Ferguson, Astronomy Explained on Sir Isaac Newton's Principles, and Made Easy to Those Who Have Not Studied Mathematics, London, 1756.

22 See, for instance, B. Martin, The Young Gentleman and Lady's Philosophy, in a Continued Survey of the Works of Nature and Art. By the Way of Dialogue, 2 vols., London, 1759; J. Newbery, The Newtonian System of Philosophy (1761); J. Ferguson, The Young Gentleman and Lady's Astronomy, London, 1768. On these publications and their wider cultural and social meaning see David Kaiser, 'Consuming philosophy: genre, gender and gentility in eighteenth-century English popularization of Newtonianism', unpublished paper, 1996. On the connection between 'politeness' and 'philosophy' see also the preface to B. Martin, $A$ Course of Lectures in Natural and Experimental Philosophy, Reading, 1743. On consumerism, gentility and culture see N. McKendrick, J. Brewer and J. H. Plumb, The Birth of a Consumer Society: The Commercialization of Eighteenth-Century England, Bloomington, 1982; J. Brewer and R. Porter (eds.), Consumption and the World of Goods, New York, 1993; A. Bermingham and J. Brewer (eds.), The Consumption of Culture, 1600-1800: Image, Object, Text, New York, 1996. See also P. Langford, A Polite and Commercial People: England 1727-1783, Oxford, 1989; and P. Earle, The Making of the English Middle Class: Business, Society, and Family Life in London, 1660-1730, Berkeley, 1989. On France see G. Sutton, Science for a Polite Society: Gender, Culture, and the Demonstration of Enlightenment, Boulder, 1995. 
space of its production to the civilized space of its public consumption. The transfer was successful only when philosophical knowledge could be reshaped in the forms of genteel conversation. Algarotti likened the domestication of natural philosophy and mathematical sciences to their being touched by female hands. The key move in this process consisted in channelling the essence of the arguments while excluding mathematical formalism. Thus Algarotti banned lines, figures and abstract concepts, hiding the mathematical method behind the fresh rendering of the experiments. Imagination and attention were the only requirements needed to enter the pleasurable and affordable realm of domesticated philosophy.

Concealing the mathematical elements from the 'mortals' also promoted the celebration of Newtonian experimentalism and reinforced its cognitive authority. The chevalier often mentions the unshakeable but invisible mathematical basis of Newton's system and the mathematical ability of Newton himself, 'the greatest of all mathematicians'. This part of the new philosophy is inexorably black-boxed for the marchioness as for the lay reader. What is clear is that the discovery and contemplation of the mathematical laws of the world are a demanding activity, and that only an ideal man incarnating a series of distinctively masculine virtues can carry it out successfully. Lay readers are left admiring and respectful, and conscious that they will never enter 'the inner part of the temple'.

\section{Testing light and people}

At the core of Newtonianism for Ladies is the literary replication of a few optical experiments, described and discussed in the fourth and fifth dialogues. The preceding discussion had led to them as to a crucial test. In the following and final dialogue the implications of their results are shown in their truly universal scope. The experiments portrayed partially overlap with those replicated by Algarotti in 1728 at the Institute of Sciences of Bologna. An in-depth historical analysis of the actual form and meaning of these experiments would take us far from Newtonianism for Ladies. However, it is important to understand the role that these experiments played in the cultural life of the 1730s, as Algarotti also aimed to use his book to continue a philosophical and ideological battle which he had begun by manipulating prisms.

Algarotti's experiments were designed to test the immutability of spectral colours. In one of these experiments, using an apparatus consisting of two holes placed about seven feet apart and one prism, Algarotti was able to pass a portion of the spectrum (red) through a second prism, showing that there was no colour change. These were not the first experiments of this kind to be held at the Institute of Sciences of Bologna. Zanotti had already set up similar experiments, but replication had failed. Instead spectral colours kept changing when passed through the second prism, quite in agreement with the results of the French experimenter Edme Mariotte. Already a faithful Newtonian, Zanotti blamed the failure on his limited experimental skills and on some deficiency, not yet identified, of the experimental apparatus. The key to Algarotti's success was precisely that of localizing the deficiency in the prisms. The Bolognese used prisms made of Venetian glass, which contained impurities and bubbles and these, Algarotti reasoned, 
caused uncontrollable effects. Algarotti replaced the defective prisms with British-made prisms of spato d'Islanda (calcium carbonate), hence his success. Other academicians repeated the experiment for different colours, variously rearranging the experimental apparatus, always with success. It was the most accurate and carefully reported test of its kind ever performed on the continent, and a great victory for the emerging Newtonian party. Presented and displayed as a crucial experiment, one that could prove the truth or falsity of Newton's system as a whole, this prismatic spectacle was performed again and again in front of academic and general audiences in Bologna and Venice. With aristocrats, professors and ecclesiastics eventually agreeing that the pure red they saw against the wall proved the truth of Newton's system, the space for reasonable dissent was being virtually closed and the ranks of the Newtonian party compacted as never before. Algarotti's experiments and his manipulation of the British prisms allowed the stabilization of a strong Newtonian alliance, which cut across borders and institutions. ${ }^{23}$

The alliance was first of all between Bologna and Rome, the Institute of Sciences and the Curia, experimental science and religious dogma. Natural philosophers and astronomers close to the Roman Curia had shown interest in the works of Boyle and Newton since around 1690. Attempts to replicate Newton's optical experiments had begun in Rome as early as 1707 with a monk, Celestino Galiani, passing light rays through prisms with a copy of the Optice as his only guide. Five years later, the astronomer Francesco Bianchini was in London to meet Newton and carry out a delicate cultural and political mission on behalf of the Holy See. The Catholic Church was indeed keen on promoting an apologetic experimentalism in the style of Boyle and Newton as the new hegemonic scientific ideology in Catholic Europe. Thus the eighteenth century opened with an apparently paradoxical situation. Newtonian philosophy and experimental methodology were associated with the cultural hegemony of Roman Catholicism and found supporters in Rome and Naples where, between 1729 and 1734, the Philosophical Transactions were translated and published. Instead, Newtonianism found resistance in institutions where the Galileian experimental tradition was most

23 On Venetian gentlemen inviting Algarotti to replicate his experiments in their city see Michelessi, op. cit. (9), p. xi. Zanotti's early experiments were discussed in his letters to Leprotti (1724-8), cod. Y 107 sup., Biblioteca Ambrosiana, Milan (henceforth BAM). See also Zanotti's letter to Beccari dated 5 August 1723, in F. M. Zanotti, Opere, 9 vols., Bologna, 1802, ix. Algarotti replicated a variant of Experiment 2, Book 1, Part 1; and Experiment 1, Book 1, Part 2 of I. Newton, Opticks, or a Treatise of the Reflections, Refractions, Inflections and Colours of Light [1704], New York, 1952, 23-6 and 113-16. See F. Algarotti, Dissertatio de colorum immutabilitate eorumque diversa refrangibilitate (1746), in Algarotti, op. cit. (5), ii, 366-88. Letter of Zanotti to Leprotti, dated 18 June 1728, cod. Y 107 sup., 84 r/v (BAM). On 30 June 1728 Algarotti read his Conclusiones de luce, et coloribus, divo Antonio Academiae inexpertorum patrono dicatae, Bologna, 1728, in mss. 1259 (BCT). The mathematician Domenico Vandelli brought the British-made prisms to Bologna. Commentarii de Bononiensi Scientiarum et Artium Instituto atque Academia (1731), 1, 200-1. In the spring of 1729 Algarotti was waiting for another four prisms to arrive from England, and asked to borrow those of Antonio Conti in Venice. Algarotti, op. cit. (5), x, 307. On the prisms used by Algarotti see various essays in Atti della Fondazione Giorgio Ronchi (1957), 12. On the social process of making the prisms transparent see S. Schaffer, 'Glass works: Newton's prisms and the uses of experiment', in The Uses of Experiment: Studies in the Natural Sciences (ed. D. Gooding, T. Pinch and S. Schaffer), Cambridge, 1989. On the role of theoretical assumptions in this kind of experiment see also A. Shapiro, 'The gradual acceptance of Newton's theory of light and color, 1672-1727', Perspectives on Science (1996), 4, 59-140. 
lively, like the University of Pisa, or where the practice of calculus and the physicomathematical sciences were more up to date, like the University of Padua and the mainland of the Venetian Republic. ${ }^{24}$

Passing light through British prisms Algarotti reinforced beliefs about the properties of colours as well as the solidity of the Newtonian network in Italy. Of course his success did little to convince those who were suspicious of the all-encompassing Newtonian synthesis. Among the most resilient opponents was the notorious Giovanni Rizzetti, from the provincial town of Castelfranco Veneto. Rizzetti's objections and experimental reports had caused some concern in London since first reported in 1722, forcing an ageing Newton to charge Jean Desaguliers with the replication of some experiments in front of relevant British and Italian witnesses. In August 1728 Desaguliers was again charged with responding to a series of questions raised in a new publication by Rizzetti (1727) in front of an audience that included three Italian abbots. Desaguliers published a report of these experiments together with the list of those who had witnessed them and a ravaging review of Rizzetti's book. Algarotti's experiments in Bologna were also a response to Rizzetti's doubts, which were all the more significant as they found support in important north Italian scientific circles. Traditionally portrayed as an isolated lunatic, Rizzetti was instead giving voice to doubts shared by relevant figures like Jacopo Riccati, the foremost Italian mathematician of his generation and a pioneer of the study of differential calculus. At the roots of Riccati's scepticism towards apologetic Newtonianism were serious epistemological, moral and theological concerns. The ironic remark that Newtonianism only worked with British prisms probably originated in this circle, and had little to do with patriotic pride. At stake were rather the conditions of the experiment: how to determine which conditions were relevant and which not? Why that particular kind of crystal and not others? Riccati and Rizzetti pointed at the hidden metaphysical assumptions that made the Newtonians see a crucial experiment where they saw a series of phenomena that could be explained in a number of other possible ways. Not surprisingly Rizzetti accused Algarotti of betraying the original, anti-dogmatic Galilean methodology and saw his controversy with the Newtonians as one dealing with 'a question of method'.25

24 On the Catholic Church being keen on the new experimental sciences see V. Ferrone, The Intellectual Roots of the Italian Enlightenment: Newtonian Science, Religion, and Politics in the Early Eighteenth Century, New Jersey, 1995, 1-40. On the rupture between the Galileian and the Newtonian tradition in Italy, see the review to the Italian edition of Ferrone's Intellectual Roots by D. Generali and M. De Zan in Società e storia (1985), 30, 937-46.

25 J. Desaguliers, 'An account of an optical experiment made before the Royal Society, on Thursday, Dec. 6th, and repeated on the 13th, 1722', Philosophical Transactions (1722-3), 32, 206-8. J. Desaguliers, 'Optical experiments made in the beginning of August 1728, before the president of the Royal Society and other gentlemen of several nations, upon occasion of Signior [sic] Rizzetti's Opticks, with an account of the said book', Philosophical Transactions (1727-8), 35, 596-629. The book in question was G. Rizzetti, De luminis affectionibus specimen physico mathematicum, Treviso and Venice, 1727. On Rizzetti's 'question of method' see Algarotti's letter to an anonymous recipient (n.d.), in Algarotti, op. cit. (5), x, 336-7. See also Zanotti's letter to Leprotti (1728), cod. Y 107 sup., 91 r (BAM). On the impossibility of reasoning with Rizzetti see Algarotti's letter to Marcantonio Caldani (1759), in Algarotti, op. cit. (5), x, 26-32. On Rizzetti's optical theory see F. Giudice, 'Giovanni Rizzetti, l'ottica newtoniana e la legge di rifrazione', Studi Settecenteschi 
Giovanni Poleni, Antonio Vallisneri and other high-ranking mathematicians and natural philosophers active on the mainland of the Venetian Republic raised similar concerns. Trained in the Leibnizian and Bernoullian calculus and well aware of the heuristic possibilities offered by the new methods of mathematical quantification, they admired Newton the mathematician and the Principia, but did not share the theological approach to Newtonianism characteristic of the Roman group. A gulf seemed indeed to separate the sophisticated mathematical descriptions of empirical phenomena produced by the Venetians both from the knowledge of the metaphysical principles of reality and from theology. In the theological pages of Riccati, for instance, the adhesion is apparent to a radical metaphysical dualism that could hardly go along with the notion of God as clockmaker or the notion of space as sensorium dei. Riccati's God is absolutely distant and enigmatic and his spiritual sensibility at odds with the benign apologetic Newtonianism blessed by the Curia. This severe Catholicism bears rather the mark of the influential religious reformer Lodovico Antonio Muratori. Although scarcely studied today, Muratori's treatment of the relationship between faith and reason seems to have been an important cultural resource for local elites struggling their way between reform and tradition in eighteenth-century Catholic Europe. ${ }^{26}$

Bologna, politically dependent on Rome but also close to Venetian culture, mediated between these different cultural programmes. Those running the Institute of Sciences knew only too well that the apparently innocuous debate over prisms could have disruptive consequences at the philosophical, religious and political level. The tones of the controversy were kept low so as not to provoke excessive reactions from either side. While certainly promoting Newtonian experimentalism, the Bolognese Institute avoided any serious engagement on metaphysical issues. Had the controversy become more radical, Rome would have pressed for explicit professions of faith and enforced a

(1998), 18, 45-63. The present interpretation clearly contrasts with the view of Rizzetti's anti-Newtonian battle as an isolated and historically irrelevant episode to be found in P. Casini, 'Newton in Italia, 1700-1740. Note di ricerca', in Newton e la coscienza europea, Bologna, 1983, 173-227, 202-7. On the ironic remarks about the British prisms as 'the only means to learn the science of colours', and the priority of the theoretical framework, see J. Riccati, De’ principi e dei metodi della fisica, in idem, Opere, 4 vols., Lucca, 1761-5, ii, 485-6.

26 On the relations between mathematics, natural philosophy and theology in Riccati see his Saggio intorno al sistema dell'universo, in Riccati, Opere, op. cit. (25), i, 4-432. See also his Dell'analogia fra i suoni ed $i$ colori, e del vero modo di filosofare in Fisica (1736), in Opere, op. cit. (25), iii, 479-500; and two letters in defence of Rizzetti (1728), in Opere, op. cit. (25), iv, 109-22. See also M. L. Soppelsa, 'Jacopo Riccati e l'Illuminismo filosofico e scientifico veneto', in I Riccati e la cultura della Marca nel Settecento europeo (ed. G. Piaia and M. L. Soppelsa), Florence, 1992, 27-73. On Muratorian culture and the practice of sciences see Mazzotti, op. cit. (17). Among Muratori's most influential works were Delle riflessioni sopra il buon gusto nelle Scienze e nelle Arti di Lamindo Pritanio, Venice, 1708; De ingeniorum moderatione in religionis negotio, Paris, 1714; Della forza dell'intendimento umano, o sia il pirronismo confutato, Venice, 1745. On Muratori see A. Vecchi, L'opera religiosa del Muratori, Modena, 1956; E. Zlabinger, Lodovico Antonio Muratori und Österreich, Innsbruck, 1970; and C. Continisio, Il governo delle passioni. Prudenza, giustizia e carità nel pensiero politico di Lodovico Antonio Muratori, Florence, 1999. Former interpretations of early eighteenthcentury Venetian culture have emphasized its radical components while overlooking important religious currents such as the Muratorian. See Ferrone, op. cit. (24), 89-121; and J. Israel, Radical Enlightenment: Philosophy and the Making of Modernity, 1650-1750, Oxford, 2001, 677-83. 
stricter control on the scientific activities of the Institute - hardly an appealing prospect for men like Zanotti and Manfredi.

The mediating strategy chosen by the Bolognese professors can explain why in the first volume of the Acts of the Institute of Sciences (1731) there was no trace of the account in which Algarotti described his optical experiences. Instead one finds an antiNewtonian memoir on mechanics by Rizzetti, himself a correspondent member of the Institute. In one of the memoirs Zanotti referred to Algarotti's experiments, but as an aside, while discussing the properties of the famed Bologna stone (barium sulphate). Meanwhile, Thomas Dereham from Rome was asking Manfredi to send Algarotti's report to the Royal Society of London for publication in the Transactions, to add to Desaguliers's anti-Rizzettian campaign, but the report never arrived. Similarly Algarotti translated into Italian Desaguliers's essay against Rizzetti and circulated it in Bologna, but ultimately decided not to publish it, as it would have been 'too great an act of hostility' 27

It was in Newtonianism for Ladies, almost ten years after the original experiments, that Algarotti eventually delivered his anti-Rizzettian attack. In fact, the image of Rizzetti as an isolated incompetent was forged precisely in these dialogues. No names are mentioned, and reference is made only to 'an adversary' of the great Newton. However, from the simple description of the experiments in question, every informed reader would have known who was being ridiculed. Some more recent commentators have thought it was Mariotte, but it is interesting to note precisely the different, much more respectful, treatment reserved for Mariotte, named explicitly in a different passage. $^{28}$

The Newtonian campaign Algarotti had begun with the 1728 experiments was thus being continued in Newtonianism for Ladies with an operation of cultural and social marginalization. Not only was Rizzetti a bad experimenter and the defender of a stale philosophy, but he was also a provincial bore. Certainly he was not somebody capable of engaging in genteel conversation. The anti-Newtonian is also the arch-enemy of cosmopolitan genteelness. This bad, embittered philosopher who lacked polite manners could never be a member of the bel mondo. Precisely because he was a deficient social being, Rizzetti could not engage in fruitful philosophical debates with his opponents,

27 Algarotti officially reported on his successful experiments on 7 April 1729. See Registro degli Atti dal 1723 al 1804, Archivio della Antica Accademia delle Scienze di Bologna. See also A. Angelini (ed.), Anatomie accademiche. Vol. 3: L'Istituto delle Scienze e l'Accademia, Bologna, 1993, 326. Rizzetti's memoir was 'De corporum collisionibus, et inde orta motuum comunicatione ad Franciscum M. Zanottum Epistola', Commentarii de Bononiensi Scientiarum et Artium Instituto atque Academia (1731), 1, 497-514. See also Zanotti's comments (213-32). Reference to Algarotti's experiments was made in F. Zanotti, 'De lapide bononiensi', Commentarii de Bononiensi Scientiarum et Artium Instituto atque Academia (1731), 1, 181-205. On the manuscript that was never sent see Manfredi's letters in the appendix of Saggio delle Transazioni Filosofiche della Società Regia dall'anno 1720 fino a tutto l'anno 1730, 5 vols., Naples, 1734. See also Manfredi's letter to Algarotti (1729), in Algarotti, op. cit. (5), xi, 38-9. The last quote is from a letter of Algarotti to Zanotti (1732), in Algarotti, op. cit. (5), xi, 386.

28 Algarotti, op. cit. (1), 178. The name of Mariotte is suggested in F. Algarotti, Dialoghi sopra l'ottica neutoniana (ed. E. Bonora), Turin, 1977. An eighteenth-century reader had correctly identified Rizzetti on a copy of the first edition of Newtonianism for Ladies now at the Burndy Library of the Dibner Institute, MIT, Boston. 
unlike the polite and well-meaning Mariotte. While Mariotte is puzzled by his experimental results, Rizzetti works on a priori principles with the egoistic intent of building his own anti-Newtonian system. Blinded by pride, envy and provincial ignorance, the ambitious Rizzetti is incapable of seeing what every cosmopolitan gentleman and lady can see. The contrast between the local, provincial dimension of Rizzetti's philosophical life and the cosmopolitan, universalistic dimension in which the chevalier and the marchioness move is absolute and irremediable. ${ }^{29}$

Understandably Zanotti and Manfredi were not too pleased when they first read the manuscript of the dialogues. Provoking Rizzetti in that fashion put at risk the delicate equilibrium between the various religious, philosophical and political components of Italian culture, thus compromising their attempt to promote a moderate and orthodox Newtonian experimentalism. Clearly Algarotti no longer shared the cultural strategy of his teachers, if he ever had done. While Algarotti's 1728 experiment had sanctioned the holy alliance of Bolognese science and Roman theology, his Newtonianism for Ladies supported an altogether different cultural strategy. It was not just the attack on Rizzetti; the very opportunity of the appeasement of religious dogma and modern natural philosophy was rejected. Algarotti's Newtonianism was hardly apologetic. Indeed, the supreme architect of the universe is remarkably absent from the pages of Algarotti's book. Of all the popular versions of Newtonian philosophy that appeared in Europe in those years, including Voltaire's theistic rendering, Algarotti's was the only one to be condemned by the Catholic Church. ${ }^{30}$

\section{The forbidden Newtonianism}

When Zanotti and Manfredi first warned Algarotti of the potential risk of publishing his dialogues they thought that his explicit adhesion to heliocentrism and the erotic overtones of his prose might have irritated the Holy Office. And indeed similar remarks have been made by historians trying to explain the reasons behind the 1739 condemnation. However, the real problem with the book proved to be of a different kind. One way of unearthing the forbidden Newtonianism for Ladies consists in comparing the first edition of the book with its 1746 edition, in which Algarotti modified the text substantially in a belated attempt to comply with the informal suggestions of the Holy Office. Further modifications along the same lines were made in the 1750 and 1752 editions, the latter being essentially the definitive version. Note that the title also changed in order to distinguish the revised versions from the condemned one. The 1746 edition, printed in Venice although still bearing the forged imprint of Naples, was entitled Newtonianism, or Dialogues on Light, Colours and Attraction. In 1750 the title

29 On the chevalier and the marchioness as citizens of the world see Algarotti, op. cit. (1), 175-6. 'Amiable and universal man' was the way in which Voltaire addressed Algarotti. Michelessi, op. cit. (9), p. cxi. On Algarotti's 'universal spirit' see also the letter of Eustachio Zanotti to Algarotti (1740) in Algarotti, op. cit. (5), xii, 348.

30 Index librorum probibitorum, Rome, 1744, 379. Algarotti's relations with Mons. Leprotti in Rome were already quite strained in 1734, judging from a letter he wrote to Eustachio Zanotti. Algarotti, op. cit. (5), x, 299. 
was reduced to the sober Dialogues on Light, Colours and Attraction. None of these editions entered the Index. ${ }^{31}$

Algarotti reorganized, revised and enriched his materials. He also revised his style, partly in response to criticisms of his less than classic Italian. For our present purposes it is important to focus on those parts of the texts that were reduced or disappeared altogether due to Roman pressure. Among these were a few inconvenient passages, like a joyful description of spermatozoa, but the more consistently cut passages had little to do with Algarotti's eroticized science. Instead they were expressions of a radical sensationalist epistemology that Algarotti seems to have derived mostly from John Locke. Although Locke was never named in the text, his ghost haunted Newtonianism for Ladies from the beginning to the end. Algarotti's celebration of Newtonian experimentalism is subtly but constantly associated with the adoption of a sensationalist perspective. In 1735 Voltaire remarked that Algarotti knew 'his Locke' as well as 'his Newton'; Newtonianism for Ladies was indeed a celebration of both as the fathers of modern philosophy. ${ }^{32}$

Algarotti showed a great deal of interest in Locke's discussion of the so-called problem of Molyneux and in its epistemological implications. He must have been also intrigued by unorthodox readings of Locke's notorious passage on the self-organizing faculties of matter, a theme that surfaced in his Newtonianism for Ladies. In the 1730s Locke was at the peak of his popularity in Europe, and Rome was well aware of the possible subversive uses of his works. The Holy Office condemned Locke's An Essay Concerning Human Understanding in 1734 and his Reasonableness of Christianity as Delivered in the Scriptures in 1737. Over-zealous polemicists like Cardinal Gerdil accused Locke of atheism and Socinianism, but also religious reformers like Muratori considered his works too prone to dangerous readings. No wonder that Locke's name ended up in very bad company in Moniglia's Dissertation against Materialists and other Non-believers (1750). Even the more enlightened members of the Curia, those who supported a moderate and apologetic Newtonianism, were concerned with the theological and political consequences of Locke's epistemological scepticism, not unlike

31 This line of interpretation has been suggested by Mauro De Zan, 'La messa all'Indice del Newtonianesimo per le dame di Francesco Algarotti', in Scienza e letteratura nella cultura italiana del Settecento (ed. R. Cremante and W. Tega), Bologna, 1984, 133-47. On heliocentrism as the main problem see Ferrone, op. cit. (24), 13. On the changing attitude of the Curia see De Zan, 'La messa all'Indice', 139-40. The first version of the Newtonianism had two editions in 1737 and two in 1739 . The most significant modifications are to be found in the following editions: Il Neutonianesimo ovvero dialoghi sopra la luce, i colori, e l'attrazione, Naples [i.e. Venice], 1746 (note that the letter 'w' is replaced by a 'u', a concession to linguistic purism); Dialoghi sopra la luce, $i$ colori, e l'attrazione, Berlin, 1750; and Dialoghi sopra la luce, $i$ colori, e l'attrazione, Naples [i.e. Venice], 1752. While preparing the 1746 version, Algarotti received from Leprotti a list of modifications required by the Holy Office. Father Orsi, Secretary of the Congregation, was pleased with this version and the pontiff gave his approval to the publication. See letters of Zanotti to Algarotti (1746-7) in Algarotti, op. cit. (5), xii, 244-51. Father Orsi was even more pleased with the 1750 version. See the letter of Flaminio Scarselli to Algarotti (1751), in Algarotti, op. cit. (5), xiii, 211. See also De Zan, 'La messa all'Indice' and Arato, op. cit. (7).

32 On spermatozoa see Algarotti, op. cit. (1), 109. On Algarotti's books as dangerous for youth because morally corrupted see its review in Novelle della repubblica letteraria (1738), 15, 115-16. Voltaire's quote is from his letter to Thiérot (1735) cited in Yates, op. cit. (9), 50. 
Samuel Clarke and a number of latitudinarians and defenders of the new natural philosophy in Britain. Already in 1722 Cardinal Davia had written to Manfredi about the dangers of the Essay, which was circulating on the continent in various French and Latin translations. Around the same time Zanotti wrote a commentary on the Essay in which he argued against Locke's rejection of innate ideas. Without innate ideas, Zanotti claimed, there could not be any universal a priori truths or therefore any scientific knowledge. Here Zanotti used Malebranche and Newton's system of attraction as resources to criticize Lockean epistemology and its alleged materialistic implications. The Roman promotion of apologetic experimentalism, substantially supported by the Bolognese Institute of Sciences, was directed at breaking the connection between experimentalism, sensationalism and materialism, much in continuity with the seventeenth-century battle against the Epicurean readings of Galilean corpuscularism. Algarotti's dialogues were quite simply pushing in the opposite direction. ${ }^{33}$

That the young Algarotti was keen on dangerous readings was no mystery to his close friends in Bologna. In 1733 Zanotti had written to Manfredi about the worrying philosophical explorations of their pupil. He described Algarotti's unhealthy inclination towards radical sensationalist theories of knowledge as 'a slow Lockean fever'. How this fever shaped Newtonianism for Ladies emerges, for instance, in the pages devoted to the eulogy of experimental philosophy in dialogue four, or in the accurate discussion of vision and of the Molyneux problem that opened the third dialogue. The latter developed into a discussion on perception and habit that culminated in the sense of touch being given pre-eminence in the construction of human knowledge. Both sections were reduced in 1746 and disappeared entirely in 1750 . Together with them the positive evaluation of ancient atomism also disappeared, as did the many remarks on the incompatibility of religion and experimental science. Instead the critique of Rizzetti was to become more explicit and relevant in subsequent editions, suggesting that the attack against Venetian anti-Newtonian culture was not unpopular with the Holy Office. ${ }^{34}$

33 For attacks against Locke see G. S. Gerdil, L'Immortalité de l'âme démontrée contre Locke et défense du P. Malebranche contre ce philosophe, 2 vols., Turin, 1747-8; letters of Muratori to Domenico Brichieri Colombi (1742) quoted in Graf, op. cit. (20), 378-9; V. Moniglia, Dissertazione contra i materialisti e altri increduli, Padua, 1750. On the British debate see N. Wood, The Politics of Locke's Philosophy: A Social Study of An Essay Concerning Human Understanding, Berkeley and Los Angeles, 1983, 54. On the reception and uses of Locke's epistemological and religious scepticism see also J. Yolton, Locke and the Way of Ideas, Bristol, 1996; and idem, Locke and French Materialism, Oxford, 1991. The letter of Davia to Manfredi is in Collezione Autografi, p. xxiii, Biblioteca Comunale dell' Archiginnasio, Bologna (henceforth BCAB). Zanotti's manuscript is F. M. Zanotti, Notae ad Lockium and Cose singolari, in Note spettanti a Filosofia morale, Fisica, Metafisica et altre spettanti alla Retorica e alla Poetica di Fr. M. Zanotti, Canterzani mss, 4177, caps. 51, n. 1, Biblioteca Universitaria, Bologna. The manuscript has been transcribed and translated by M. de Zan in Rivista Critica di Storia della Filosofia (1983) 38, 471-96, who also comments on Davia's 1722 letter. On Davia see G. Brizzi, sub voce, p. xxxiii, DBI, 127-30.

34 As early as 1729 Manfredi would invite Algarotti to be more cautious in 'those matters about which one does not want to talk and even less write'. He would also use the expression 'your English [authors]'. Algarotti, op. cit. (5), xi, 39-40, 48. In the early 1730s Algarotti was reading and appreciating authors like Pietro Giannone and Giordano Bruno. See letter of Algarotti to Zanotti (1732), in Algarotti, op. cit. (5), xii, 66; and letter of Sebastiano Antoni to Algarotti dated 30 December 1731, in Epistolario Moschini, Biblioteca del Museo Correr, Venice. In 1733 Zanotti reported that Algarotti was doing well in integral calculus and mechanics but was affected by a slow Lockean fever (una certa febbre lenta di Lochismo) and a strong 


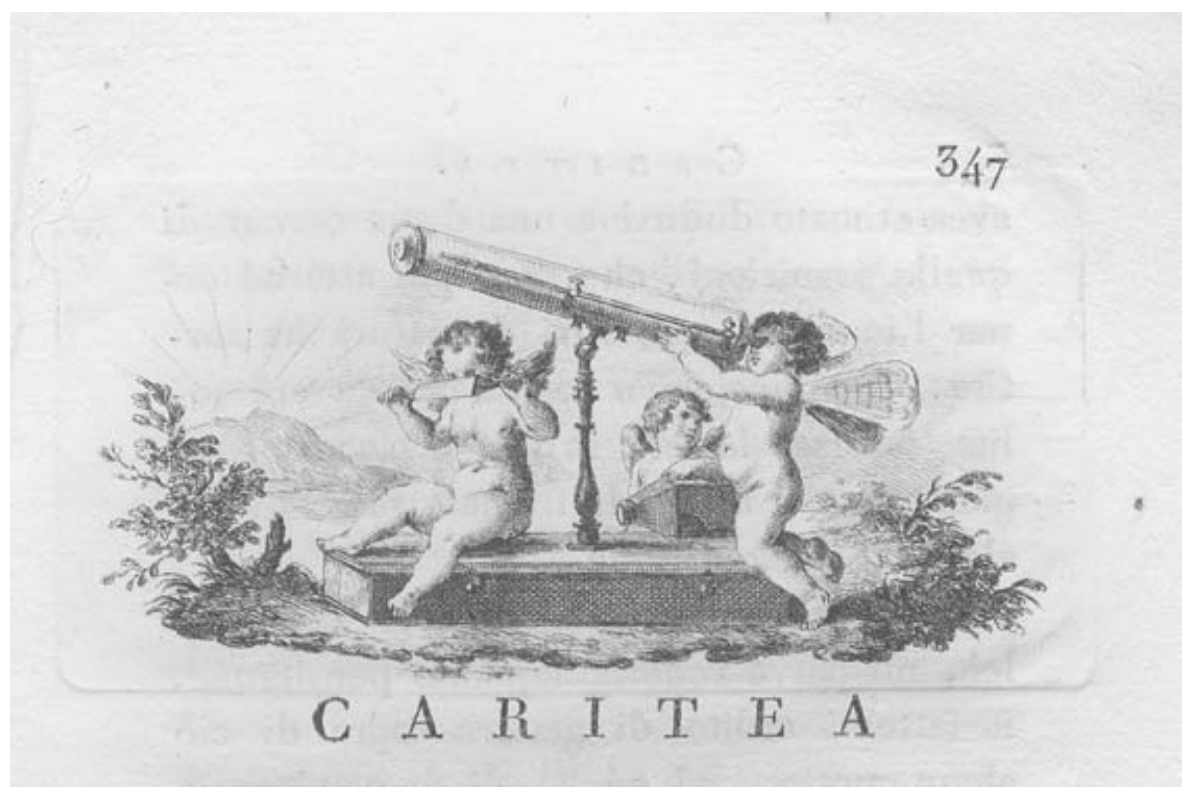

Figure 3. Allegory from the titlepage of Caritea. From F. Algarotti, Opere, 1791-4.

Algarotti would return to elaborate his radical sensationalist epistemology in Caritea, a short dialogue completed in the early 1750s. This dialogue between Algarotti and Caritea, a Venetian lady 'of great lineage', was conceived as a corollary to Newtonianism for Ladies and indeed followed it in the early editions of Algarotti's works. Caritea, who has read Newtonianism for Ladies 'with pleasure', asks Algarotti to clarify a passage in which the functioning of the eye is compared to that of a camera obscura. The dialogue focuses on the anatomy of the eye and the physiology of vision. Algarotti refers to the problem of Molyneux and then, with a coup de théatre, offers the

attraction for libertine authors. Lettere familiari d'alcuni bolognesi del nostro secolo, Bologna, 1744, ii, 101-2. William Molyneux was the author of Dioptrica Nova: A Treatise of Dioptricks (1692). See J. Simms, William Molyneux of Dublin, 1656-1698 (ed. P. Kelly), Blackrock, 1982. The 'problem of Molyneux' dealt with the issue of whether 'the experience derived from one field of sense perception is a sufficient basis on which to construct another field of perception that is of qualitatively different content and of specifically different structure' (E. Cassirer, The Philosophy of the Enlightenment, Princeton, NJ, [1932] 1968, 108). The problem first appeared in print in Some Familiar Letters between Mr. Locke and Several of his Friends, London, 1708, 37-8. It had the following form: would a person born blind, on recovering the use of his eyes, be able to name correctly a cube and a sphere on the basis of his previous tactile experience with these objects? See also J. Locke, An Essay Concerning Human Understanding, Amherst, N.Y., [1693] 1995, 93-4. On the significance of Molyneux's question see also J. Davis, 'The Molyneux problem', Journal of the History of Ideas (1960), 21, 392-408; A. Bernabei, 'Il cieco di Molyneux: un problema della percezione visiva nella Francia illuminista, 1737-1754', Rivista Critica di Storia della Filosofia (1975), 30, 132-66; and M. Degenaar, Molyneux's Problem: Three Centuries of Discussion on the Perception of Forms, Dordrecht, 1996. Note that Algarotti was extremely displeased when the letter containing the reference to his Lockean fever was published in 1744, just as he was preparing his revised edition of Newtonianism for Ladies. The passage caused a great sensation in Bologna. See the letters between Algarotti and Zanotti (1745), in Algarotti, op. cit. (5), xii, 211-21. 
lady an unexpected empirical solution: William Cheselden's report of the case of a blind man acquiring his sight after a surgical intervention. It is a solution that reinforces the more radical empiricist account of vision, making it analogous to a language that is acquired only through use and habit. It is the sense of tact, Caritea concludes, that rules all our ideas. While Newton drifted into the background, Algarotti seemed to be engaging more and more with Condillac, La Mettrie and Diderot, emphasizing the epistemological scepticism and materialist overtones already present in his main book. The continuity between the first version of the Newtonianism for Ladies and Caritea is indeed clear, and there is no need to postulate a 'conversion' of Algarotti, or his missing the political and religious implications of his epistemological position. The first version of Newtonianism for Ladies already contained a detailed discussion of the problem of vision, and even a reference to the surgical intervention that had provided empirical answers to these philosophical questions..$^{35}$

As for the broader implications of this position, Algarotti's 'eulogy of experimental philosophy' was an exemplary illustration of how radical sensationalism and Newtonianism could be joined to threaten religious orthodoxy and social order. In this section the methodological model of Newton's Opticks was shown to be relevant well beyond the limits of natural philosophy. In a few pages, the reader was invited to admire the results of the 'industrious philosophy' in physics as well as in medicine, history and the design of political systems. The eulogy of experimentalism culminates in an open celebration of British culture and political life, and with the recognition of the role of Newtonian experimentalism in the battle against religious obscurantism. Newtonianism for Ladies openly rejected both transcendentalist and rationalist doctrines that dominated cultural life on the continent, best incarnated by the success of Malebranchian philosophy. Instead of offering a compromise with religious and philosophical tradition, Algarotti invited the adoption of a sceptical and sensationalistic epistemology, on the basis of which the new experimental methodology could be imported into every sphere of human action, including metaphysics, morals, economics and politics. Algarotti stated clearly the political relevance of his dialogues in the opening letter to Fontenelle, which disappeared in the 1750 edition:

May the age of things and of universal learning come upon us, when knowledge may serve not to harden hearts, nor to nourish the minds of the few, nor to make us suffer upon ancient and outmoded speech but rather, where possible, to improve and adorn society. ${ }^{36}$

35 F. Algarotti, Caritea, in cui si spiega come da noi si veggano diritti gli oggetti che nell' occhio si dipingono capovolti, e come solo si vegga un oggetto non ostante che negli occhi se ne dipinga due immagini, in Algarotti, op. cit. (5), ii, 347-65. Algarotti's friend and first biographer Michelessi claimed indeed that Caritea was 'a compendium of the entire book [Newtonianism for Ladies]'. Michelessi, op. cit. (9), p. xiii. W. Chesselden, 'An account of some observations made by a young gentleman, who was born blind, or lost his sight so early, that he had no remembrance of ever having seen, and was couch'd between 13 and 14 years of age', Philosophical Transactions (1727-8), 35, 447-50. The arguments of conversion and unawareness are made in B. Basile, 'Un dialogo scientifico di Algarotti: Caritea', Filologia e Critica (1984), 9, 254-73. But see instead the relevant passages in Algarotti, op. cit. (1), 93-107.

36 'Il secolo delle cose e dell'universal cultura venga una volta anco per noi, e il sapere non ad irruvidir l'animo, a nutrir d'alcuni pochi la mente, o a patire sopra una vecchia e disusuata frase, ma a pulir serva, se possibile, e ad abbellir la società'. Algarotti, op. cit. (1), p. xi. 
Cultivating modern experimental philosophy would open an age of social and economic reform. Newtonianism is more than a philosophical doctrine; it is a mode of thought and a form of life. Through the example of Great Britain the connection between experimental philosophy, economic prosperity and political-military power is made obvious to the reader. Through British science Algarotti was celebrating those political and administrative institutions that could truly regenerate continental Europe, as once Roman governance had done. ${ }^{37}$

Algarotti's radical and anti-religious overtones and his reference to social and political reform were grounded not only on Lockean epistemology, but also on various resources derived from the tradition of seventeenth-century libertinage. In the 1730s, when he was writing up his dialogues, this radical culture was being re-elaborated in new centres of sociability like coffee houses, conversazioni and the early masonic lodges. And it is precisely Algarotti's masonic connections that provide us with a coherent itinerary into the forbidden Newtonianism for Ladies. ${ }^{38}$

Describing how he had kept mathematical reasoning out of his dialogues and his knowledge of calculus hidden, Algarotti used an interesting metaphor. While he had accompanied the profane through the doors of the temple, he had not let them into its 'sanctuary', a site that 'has always been reserved for the priests'. The recurring motif of the Newtonian temple is related to the attempt to domesticate natural philosophy by removing mathematical formalism from the sight of the audience. However, Algarotti's terminology and imagery worked also at a different level. In using language referring to the temple and its holy of holies, to the demarcation between the profane and the initiated, to the suggestion that there exists a core of esoteric knowledge that can provide a true understanding of reality, he was deliberately echoing a masonic discourse. And indeed the philosophical journey of the marchioness through the six dialogues

37 Algarotti, op. cit. (1), 153; and Graf, op. cit. (20), 140-55. See also Algarotti's letter to an anonymous recipient (1752) on the connection between a free government, culture and wealth, in Algarotti, op. cit. (5), ix, 214-15. Knowing calculus, Locke and the law of gravitation is not enough, Algarotti remarked. One also needs to know the Act of Navigation, the excellence of the English government, its laws, Swift, Pope and the proper way of manuring the land. Letter to Antonio Zanon (1763), in Algarotti, op. cit. (5), $\mathrm{x}, 165-8$. There is a vast literature on the relation between Newtonian science and contemporary economic and technological development, which goes back to the pioneering works of Boris Hessen and Robert K. Merton: B. Hessen, 'The social and economic roots of Newton's Principia', in Science at the Crossroads (ed. N. Bukharin), London, 1931, 1-62; and R. Merton, Science, Technology, and Society in Seventeenth-Century England, New York, [1938] 1970, 228-8. See also S. Schaffer, 'Newton at the crossroads', Radical Philosophy (1984), 37, 23-8. For more recent studies see I. Inkster, 'The public lecture as an instrument of science education for adults: the case of Great Britain, c. 1750-1850', Paedagogica Historica (1981), 20, 80-107; L. Stewart, 'The selling of Newton: science and technology in early eighteenth-century England', Journal of British Studies (1986), 25, 178-92; idem, The Rise of Public Science: Rhetoric, Technology, and Natural Philosophy in Newtonian Britain, 1660-1750, Cambridge, 1992; M. Jacob, 'Scientific culture in the early English Enlightenment: mechanisms, industry, and gentlemanly facts', in Anticipations of the Enlightenment in England, France, and Germany (ed. A. Kors and P. Korshin), Philadelphia, 1987, 134-64; M. Jacob, Newton and the Culture of Newtonianism, Atlantic Highlands, NJ, 1995.

38 On the links between early freemasonry and radical thought see M. Jacob, The Radical Enlightenment: Pantheists, Freemasons and Republicans, London, 1981; and idem, Living the Enlightenment: Freemasonry and Politics in Eighteenth-Century Europe, Oxford, 1991. But see also G. Gibbs, Review of The Radical Enlightenment, BJHS (1984), 17, 67-81. 
mimicked a process of masonic initiation. Note how, towards the end of the final dialogue, the fundamental revelation about the forces that regulate the machine of the universe is introduced by the invitation to the marchioness to abandon what is left of the profane in her, and by a typical ritual questioning: 'Tell me, my lady, how much do you desire Truth?' Algarotti then invokes the spirits of light before revealing the most sublime mysteries of Newtonian philosophy, those that are normally 'hidden from the gaze of mortals'. The darkness of 'a deep night' needs to be dispelled in order to see them. The motif of the triumph of light over darkness had clear masonic resonances and was becoming increasingly popular in the frescoes of Venetian country villas. ${ }^{39}$

Of course this is a light, tongue-in-cheek initiation. At the opening of the third dialogue the marchioness is impatient to learn about the modern theory of vision: 'I told her that we had to approach such high-degree knowledge in a more ceremonious way; and that it was well worth waiting for until at least after luncheon.' However, this lighthearted and sensual initiation never transmutes into parody. The important celebration of experimental philosophy discussed above opens with masonic echoes (again the sanctuary, the profane philosophers) and is concluded by the elaboration of the hermetic theme of the ritual death and rebirth. Only by embracing Newtonianism can one be reborn to a new and truly philosophical life (a novella vita rinascere in filosofia). ${ }^{40}$

During the preparation of his book Algarotti had associated himself with radical conversazioni and early masonic lodges. His associations along the route from Padua to Florence, Rome, Paris and London followed a pattern to be found in other Venetian travellers attracted in those years by radicalism and egalitarianism. His Bolognese friends knew of his 'attachment to the freemasons (francs-maçons)' and showed signs of concern, particularly Manfredi. Among Algarotti's Roman acquaintances was the British resident Martin Folkes, the promoter of a libertine-inspired freemasonry and the man who would invite him to join the Royal Society of London in 1736. And it was in his meeting with Folkes, 'gentleman of rare doctrine', that Algarotti discussed Locke and the problem of Molyneux in depth. In Florence, Algarotti frequented the physician Antonio Cocchi and the poet Tommaso Crudeli, the men who ran the local masonic lodge. Cocchi, himself a member of the Royal Society of London, was a well-known defender of 'British wisdom' in natural philosophy, which to him meant first of all Newton, whom he had met in 1723, and Locke, whom he studied first-hand in the library of Pierre Coste. His medical works were framed in a radically sensationalist epistemology, while some non-circulated anatomical notes revealed the full extent of his anti-teleological and materialist natural philosophy. As for Crudeli, he was a fine rococo poet and an outspoken freethinker in the tradition of seventeenth-century Tuscan libertinism. In his poems, eroticism and sensuality blended with the motif of the

39 On Algarotti's mathematical training and his ability in concealing it as opposed to Voltaire's incompetence see Manfredi's letter to Algarotti (1739), in Algarotti, op. cit. (5), xi, 144. On Algarotti's 'extraordinary talent' in mathematics see also the letter of Manfredi to Algarotti (1731), in Algarotti, op. cit. (5), 55-6. Quotes from Algarotti, op. cit. (1), 284-5. On the theme of light in Venetian frescoes and its connection to reform see B. Mazza, 'Il trionfo della scienza ovvero la luce dell'intelligenza vince le tenebre dell'ignoranza', Studi Veneziani (1992), 23-4, 163-81.

40 Algarotti, op. cit. (1), 91, 157. 
triumph of reason and the republican ideal. The Roman republic, Machiavelli, Locke and modern experimentalism were favourite topics for discussion in this Florentine circle, and would be central to Algarotti's literary production as well. Algarotti had 'infinite consideration' for the judgement of Crudeli who, in return, appreciated the poetic efforts of the young Venetian. From Florence Algarotti wrote half-jokingly to Zanotti that he would not be surprised if after reading his recent poetry he should turn 'Lockean and Epicurean'. Note also how in 1738 Algarotti made sure that Crudelihimself the author of an Art of Pleasing Women and the Amiable Companies - was among the first to receive a copy of Newtonianism for Ladies. This was a risky move, considering that the poet was strictly controlled by religious authorities and Algarotti's book was a clandestine publication without imprimatur. ${ }^{41}$

The ecclesiastical authorities in Rome knew of Algarotti's unorthodox frequentations, of course. Already in 1734 Monsignor Leprotti acknowledged that Algarotti was a member of 'the famous company of the freemasons (des libres maçons)'. However, he reassured Manfredi that his pupil had managed to avoid irritating the Roman community of Jacobite exiles. The attitude of the Catholic Church towards the early lodges was becoming more and more rigid, though, and the second half of the 1730s saw a vast repressive operation conducted in coordination with local governments all over Europe. In April 1738 Clement XII promulgated the first papal bull against freemasonry, which provided the legal weapons for persecution. Although the bull spoke of the dangers of secret societies, the real target was the lodge as a new and uncontrolled site of cultural production and social experimentation. The political crisis of the Grand Duchy of Tuscany was the specific event that triggered the repression. The Florentine lodge of

41 According to Michelessi, during his early travels Algarotti did not only improve his philosophical knowledge, but also his 'political and moral knowledge'. Michelessi, op. cit. (9), p. cxxi. See also R. Targhetta, La massoneria veneta dalle origini alla chiusura delle logge (1729-1785), Udine, 1988, 32-7; and F. Trentafonte, Giurisdizionalismo, Illuminismo e massoneria nel tramonto della repubblica veneta, Venice, 1984, 68. On Algarotti's attachment to the freemasons see the letter of Manfredi to Leprotti dated 29 June 1737, Carteggio Manfredi, iii (BCAB). See also the letter of Leprotti to Manfredi dated 14 December 1737, Carteggio Leprotti, iii (BCAB). But see also the letter of Keyserlings to Algarotti (1740), where one reads, '[Frederick II] c'est declaré Maçon, et moi de même a la suite de mon Héros. Considerez-moi comme un maitre Maçon. ... Je la salue por tous le cinq points de géométrie.' In Algarotti, op. cit. (5), xv, 26. On Folkes see Manfredi's letter to Algarotti (1734), in Algarotti, op. cit. (5), xi, 110. On Algarotti discussing Locke with Folkes see his letter to Gian Maria Ortes (1750), in Algarotti, op. cit. (5), ix, 166-9. On Cocchi see U. Baldini, sub voce, xxvi, DBI, 451-61; and L. Guerrini, Antonio Cocchi naturalista e filosofo, Florence, 2002, particularly 53-66, 157-9, 231. On Crudeli see P. Casini, 'The Crudeli affair: inquisition and the reason of state', in Eighteenth-Century Studies (ed. P. Gay), Hanover, NH, 1972, 131-52; and F. Sbigoli, Tommaso Crudeli e $i$ primi framassoni in Firenze, narrazione storica corredata di documenti inediti, Milan, 1884. On Machiavelli as the 'Locke of politics' and a political reading of Roman history see Algarotti, Saggio critico del triumvirato di Crasso, Pompeo, Cesare (begun in 1739), in Algarotti, op. cit. (5), xvii, 145-522. See also F. Bertini, 'La massoneria in Toscana dall'età dei lumi alla restaurazione', in Le origini della massoneria in Toscana (ed. Z. Ciuffoletti), Foggia, 1989, 43-65. See also M. Rosa, Dispotismo e libertà nel Settecento. Interpretazioni 'repubblicane' di Machiavelli, Bari, 1964; and M. Saccenti, Lucrezio in Toscana. Studio su Alessandro Marchetti, Florence, 1966. On Zanotti turning Lockean and on Crudeli see Algarotti's letters to Zanotti (1733-4), in Algarotti, op. cit. (5), xii, 103, 131, 137. For a sample of Algarotti's early poetry see his Rime, Bologna, 1733. On sending Newtonianism for Ladies to Crudeli see Manfredi's letter to Algarotti (1738), in Algarotti, op. cit. (5), xi, 127. The essay cited in the text is T. Crudeli, L'arte di piacere alle donne ed alle amabili compagnie, Paris [i.e. Florence], 1762. 
Cocchi and Crudeli was providing the site for the elaboration of a radical religious and political discourse that, due to the dynastic change of 1737 , could have reshaped the relation between the Church and the Tuscan state. Franz Stephan of Lorraine, the new ruler, was himself a well-known freemason and more than keen on the anti-Jesuit cultural policy of the radicals affiliated to the Florentine lodge. The clash for the cultural hegemony over the Grand Duchy ended with a political and cultural compromise, following which the activity of the Florentine lodge was suspended. Crudeli, being small fry, was arrested in May 1739 and died a few years later due to the hardship endured serving his sentence. ${ }^{42}$

As the main sites of radical religious and political discussion were being closed down, the text that more than others had brought to the general public the spirit of those discussions could hardly be left untouched. Newtonianism for Ladies was condemned in the same year as Crudeli, 1739. Manfredi and Zanotti had already provided Algarotti with a list of corrections for a new edition of the book. Suggestions arrived from Rome through Leprotti and his patron, the Bolognese Cardinal Giovanni Antonio Davia, a keen supporter of modern experimental philosophy and, in those years, a member of the Congregation of the Index. Manfredi's invitations to moderation and caution aimed primarily to protect the Institute of Sciences of Bologna, and the modern experimental practices that were being implemented there under the banner of apologetic Newtonianism. Instead Algarotti was offering to his more informed readers a set of radical perspectives on natural and social order. Most interestingly, he had found a way to present these ideas in a straightforward, humorous and fashionable way. Algarotti wrote that a 'spirit of freedom' (spirito di libertà) was at the basis of the relation between the chevalier and the marchioness. It emblematized the egalitarian social structures that Algarotti had found in the sociability of radical conversazioni and masonic lodges, veritable miniature models of a forthcoming regenerated society. Algarotti would remain dear to Italian freemasons and radicals well after his death. ${ }^{43}$

42 On Algarotti's affiliation to freemasonry see the letter of Manfredi to Leprotti dated 3 March 1734, Carteggio Manfredi, ii (BCAB); and the letter of Leprotti to Manfredi dated 13 March 1734, Carteggio Leprotti, ii (BCAB). The bull against freemasonry was the In Eminenti, 28 April 1738. The title reads, 'Condemnatio Societatis seu conventicularum, vulgo De' liberi muratori, aut Des francs massons, sub poenâ excommunicationis ipso facto incurrendâ, eius absolutione, excepto mortis articulo, Summo Pontifici reservatâ'. See Bullarium diplomatum et privilegiorum sanctorum romanorum pontificum, Turin, 1872, p. xxiv, 366-7.

43 On the repression of freethinking in Venice in the late 1730s, and its impact on book printing and trade, see C. Lodoli, Della censura dei libri (ed. M. Infelise), Marsilio, Venice, 2001, pp. xvi-xxi. In 1735 Giannone was expelled from the city and the Holy Office began a trial against Antonio Conti. Emblematic of Venetian freethinking in the 1730s was the activity in the shop of the hatter Bortolo Zorzi, investigated by both the State Inquisition and the Holy Office between 1737 and 1741. See F. Barbierato, 'La bottega del cappellaio: libri proibiti, libertinismo e suggestioni massoniche nel '700 veneto', Studi Veneziani (2002), 44, 327-66. More generally on freemasonry, inquisition and libertinism in the 1730s see G. Giarrizzo, Massoneria e Illuminismo nell'Europa del Settecento, Venice, 1994, 73-105. As early as February 1737 Manfredi knew that the Holy Office was displeased with Algarotti's widely circulated manuscript. He then wrote to Algarotti trying to convince him to eliminate those passages that could irritate the religious censorship. He stressed the fact that all his most dear friends living in Italy would be damaged by the foreseeable action of the Holy Office. See Algarotti, op. cit. (5), xi, 117-18. In 1739 Cardinal Davia tried to defend Algarotti from the accusations of the secretary of the Congregation of the Index, Father Ridolfi. Anyway, Leprotti was personally convinced that 
The Newtonianism ends with an erotic innuendo and the invitation not to take the whole conversation too seriously. Algarotti takes leave winking to his readers in the traditional style of seventeenth-century libertinage, but what he leaves in their hands is not as traditional a text. A hybrid between a philosophical dialogue and a manual of style and good manners, the Newtonianism was indeed a call for a new cosmopolitan elite to group under the banners of good taste and Newtonianism and win a battle that was scientific, cultural and political. Algarotti suggested that gentility and the new experimental philosophy should be put concretely to work for the regeneration of social life in continental Europe. Towards the end of the final dialogue the chevalier advises the marchioness to dissimulate her newly acquired philosophical knowledge, otherwise she might upset the social order of the microcosm of the villa. Not unlike a learned and wise woman philosopher, the initiate to the secrets of Newtonianism knew they should temporarily dissimulate the knowledge of its subversive religious and political implications. And what was more natural and distinctive for the 'graceful people' than letting readers glimpse these implications through the airy forms of rococo style and the pattern of a genteel, playful conversation?

Algarotti should not reprint his book. Manfredi suggested to Algarotti to lobby the Venetian ambassadors in Paris and London to protect his reputation in his native city. See letter of Manfredi to Algarotti (1739), in Algarotti, op. cit. (5), xi, 142-7. The 1778 editions of Algarotti's works were edited by the freemasons Lorenzo Manini and Giambattista Biffi (F. Algarotti, Opere, 10 vols., Cremona, 1778-84). See Trentafonte, op. cit. (41), 68; and Arato, op. cit. (7), 153. 